\title{
Study on toxicity of Oreochromis niloticus with aflatoxinB1
}

\author{
Sherif, A.H. ${ }^{1}$ Abdel-Maksoud, S.A. ${ }^{2}$ and Shukry, M.M. ${ }^{3}$ \\ 1- Dep. Fish diseases, Animal Health Research Institute (AHRI) - kafr El-Shiekh \\ Branch - Agriculture Research Center (ARC). \\ 2- Dep. Fish diseases, Animal Health Research Institute (AHRI) - Domitta Branch - \\ Agriculture Research Center (ARC) \\ 3- Dep. Physiology, Faculty of Vet. Med- kafr El-Shiekh Univ.
}

\begin{abstract}
The purpose of this study was to determine the effect of aflatoxin $\mathrm{B}_{1}\left(\mathrm{AFB}_{1}\right)$ on immunity and hematological profile, $\mathrm{RBC}, \mathrm{WBC}, \mathrm{Hb}$, serum protein, albumin-A, globulin-G, A/G ratio, phygocytic activity, nitro blue tetrazolium reduction and challenge test against Aeromonas hydrophilla of apparently healthy 150 Nile tilapia Oreochromis niloticus weighed $23.42 \pm 1.2$ gram. After 84 days of exposure to $\mathrm{AFB}_{1}$ 100 and $20 \mu \mathrm{g} / \mathrm{kg}$ fish samples were collected then O. niloticus were treated with biological antitoxin for 3 days then samples were taken after stoppage the treatment by 7 days. Immune activities and hematological profile were significantly $(\mathrm{P} \leq 0.05)$ influenced in dose and duration of exposure dependent manner this was reflected in the health and growth performance of $O$. niloticus. Results indicated that improvements had achieved by lowering the $\mathrm{AFB}_{1}$ compained with biological treatment.
\end{abstract}

Keyword: Aflatoxin $\mathrm{B}_{1}$, Oreochromis niloticus, immunity, blood, liver enzyme.

\section{INTRODUCTION}

Aflatoxins are mycotoxins produced as secondary metabolites by Aspergillus flavus and A. parasiticus (Cheeke and Shull, 1985). In Egypt, aflatoxins and other mycotoxins are frequently detected in feedstuffs such as cottonseed, peanut, corn, milo, rice, dried fish, shrimp, and meat meals (Hassan et al., 2002). Problems associated with mycotoxins tend to be worse in the tropics like Egypt where high humidity and temperature create optimal conditions for fungal growth. Hagazy (1988) reported that $32 \%$ of examined cereal grains and $6 \%$ of examined concentrates and fish meals contained 1-50 ppb of aflatoxin; 9\% of cereal grains and 3\% of concentrates and fish meal contained 51-200 ppb and $8 \%$ of cereal grains and $16 \%$ of concentrates and fish meal contain 201-2000 ppb.

The ingestion of aflatoxin contaminated diets led to hazard effects on fish production and health (Shehata et al., 2003 and Zaki et al., 2008). The principle aflatoxin, $\mathrm{AFB}_{1}$, is one of the most toxic of all naturally occurring carcinogens. A major epidemic of liver tumors (hepatomas), which struck US trout hatcheries in the early 1960s, was traced to contaminated cottonseed meal in the feeds (Wolf and Jackson, 1963). Aflatoxin causing damages of different organs lowering immunoglobuline production leading to increase susceptibility to infectious diseases. Aflatoxin interferes with vaccine-induced immunity in livestock and lowers the resistance to infectious diseases (Diekman and Green, 1992). Aflatoxin extraction or detoxification has proven practical for only a few feed ingredients, e.g., ammoniation of cottonseed meal has been reported to effectively detoxify the aflatoxin contaminant (Ahmad et al., 1996). So the aims of this work were to investigate the effects of 
aflatoxin $\mathrm{B} 1$ on immune status of $O$. niloticus and to evaluate the effectiveness of biological antitoxin.

\section{MATERIALS AND METHODS}

\section{1- Experimental design:}

A total number of 150 apparently healthy of $O$. niloticus were obtained from private fish farms at El-Hamol -Kafr El-Sheikh Governorate- weighing 23.42 \pm 1.2 gram. O. niloticus acclimated in fiberglass tanks for 15 days to laboratory conditions. Fish randomly distributed in glass aquarium $(50 \times 40 \times 40 \mathrm{~cm})$ containing about 60 liters of dechlorinated water and aquarium water temperature was adjusted at $25 \pm 2.5$ ${ }^{\circ} \mathrm{C}$ as well as continuous oxygen supply by air pump. O. niloticus were fed pelleted ration (purchased from local market) with daily percentage $3 \%$ of body weight six days per week. Experiment had lasted for 94 days divided into two phase 84 and 10 days.

Source of $\mathrm{AFB}_{1}$ :- $\mathrm{AFB}_{1}$ was produced through pellets fermentation using Aspergillus parasiticus NRRL 2999 according to the method described by Abdelhamid and Mahmoud (1996).

O. niloticus were divided into 5 treatments $\mathrm{T} 1, \mathrm{~T} 2, \mathrm{~T} 3, \mathrm{~T} 4$ and $\mathrm{T} 5$, each treatment had 3 replicates

T1-fed $\mathrm{AFB}_{1}$ at level $100 \mu \mathrm{g} / \mathrm{kg}$ for 84 days.

T2-fed $\mathrm{AFB}_{1}$ at level $100 \mu \mathrm{g} / \mathrm{kg}$ for 84 days then $20 \mu \mathrm{g} / \mathrm{kg}$ for 10 days.

T3-fed $\mathrm{AFB}_{1}$ at level $100 \mu \mathrm{g} / \mathrm{kg}$ for 84 days then $20 \mu \mathrm{g} / \mathrm{kg}+$ biological antitoxin $2 \mathrm{~g} / \mathrm{kg}$ diet for 3 days then $20 \mu \mathrm{g} / \mathrm{kg}$ for 7 days.

T4-fed $\mathrm{AFB}_{1} 20 \mu \mathrm{g} / \mathrm{kg}$ for 84 days.

T5- fed $\mathrm{AFB}_{1} 20 \mu \mathrm{g} / \mathrm{kg}+$ biological antitoxin $2 \mathrm{~g} / \mathrm{kg}$ diet for 3 days then $\mathrm{AFB}_{1} 20$ $\mu \mathrm{g} / \mathrm{kg} 7$ days.

Biological antitoxin:- A blend of biological substances trade name syner-tox (purchased from local market) consists of citric acid $80 \mathrm{ml}$, phosphorus acid $60 \mathrm{ml}$, malic acid $5 \mathrm{ml}$, tartaric acid $5 \mathrm{ml}$, disodium EDTA $15 \mathrm{ml}$, propylene glycol $100 \mathrm{ml}$, lactic acid $80 \mathrm{ml}$, calcium lactate $25 \mathrm{ml}$, dried bacillus subtilis fermentation extract $260 \mathrm{ml}$, sodium citrate 40 gram, papain 40 gram, distilled water $(180 \mathrm{ml})$ upto 1 liter.

Determination of $\mathrm{AFB}_{1}$ in ration:- The quantitative determination of $\mathrm{AFB}_{1}$ by quantitative thin layer chromatography TLC was carried out according to the method of Eppley (1968).

Growth performance was calculated according to the following equations:-

a-Average daily gain $(\mathrm{ADG})=(\mathrm{W} 1-\mathrm{W} 0) / \mathrm{T}$ Where, $\mathrm{W} 0$ and $\mathrm{W} 1$ were the initial and final body weight per $(\mathrm{g})$, and $\mathrm{T}$ is the number of days in the feeding experimental period (Castell and Tiews, 1980).

b-Total weight gain $(\mathrm{TG})=\mathrm{Wt1}-\mathrm{Wt} 0$ Where wt 1 is the final body weight $(\mathrm{g})$ and wt0 is the initial body weight (g) (Castell and Tiews, 1980).

c-Feed conversion ratio $(\mathrm{FCR})=$ Mass of feed intake $(\mathrm{g}) /$ body mass gain $(\mathrm{g})$ Where, the weight gain is (the biomass of fish at the start + the biomass of the dead fish- the biomass of the fish at the end) (Tacon, 1987).

d-Relative Growth Rate $($ RGR \%) $=100$ (final weight-initial weight)/Initial weight.

e-Survival rate $\%=$ No. of live fish in specific period / Total population during that period x 100 .

2- Clinical, post mortem examination and survival rate of O. niloticus:

The collected fish were clinically examined according to Amlacher (1970).

They were examined for any abnormalities exophthalmia, skin, erosion, ulcers, 
hemorrhages and detachment of scales. The collected fish were opened according to method described by Amlachar (1970). Internal organs were examined by making three cuts the first from infront of anus through abdominal cavity toward the head then the second perpendicular to the first behind the bronchial cavity and the third cut ran from anus to head parallel to the lateral line. Then the abdominal wall was removed and internal organs were investigated.

\section{3-Haemogram analysis of $O$. niloticus:}

Blood samples were taken two times, the first after 84 days and the second after 10 days. Blood film was prepared according to the method described by Lucky (1977). Red blood cell (RBCs) and White blood cell (WBCs) counts were counted by haemocytometer according to Stoskopf (1993). Mean Corpuscular hemoglobin concentrations were calculated according to the formula mentioned by Dacie and lewis (1975).

M.C.V. $=(\mathrm{PCV} / \mathrm{RBCs}) \times 10 \mathrm{as} \mathrm{m} / \mathrm{mm}^{3}$.

M.C.H. $=(\mathrm{HB}$ content $\mathrm{gm} / 100 \mathrm{ml} / \mathrm{RBCs}) \times 10 \mathrm{as} \mathrm{m} / \mathrm{mm}^{3}$.

M.C.H.C. $=(\mathrm{HB}$ content $\mathrm{gm} / 100 \mathrm{ml} / \mathrm{PCV}) \times 100 \mathrm{as} \%$.

4- biochemical analysis of $O$. niloticus:

The concentration of total protein (TP) (Weichsellbaum, 1946) and albumin (A) (Doumas et al., 1971) were measured by colorimetric methods, While, globulin concentrations $(\mathrm{G})$ were determined by subtracting the concentration of TP from A concentration.

Electrophoretic pattern of serum protein fractions was estimated using polyacrylamide gel columns (Maurer, 1971) and gel was scanned and read according to Glick (1968).

The activity of the liver enzymes, Aspartate Amino Transaminase (AST) and Alanine Amino Transaminase (ALT) were determined according to (Reitman and Frankel, 1957). The activity of the kidneys creatinine were determined according to Henry (1974) and urea was determined according to Patton and Crouch (1977) kits (dp International). Alkaline phosphatase (ALP) was measured according to (Rec, 1972) by using kits reagent supplied by Diamond Diagnostic Co.

\section{5- Immunity activities of $O$. niloticus:}

\section{a- Macrophage phagocyte indices:-}

Leukocytes isolation was performed according to the method described by Faulmann et al. (1983) and phagocytic activities were determined according to Kawahara et al. (1991). Blood was collected from the caudal vessels by syringe moisten with heparin $(100 \mathrm{IU} / \mathrm{ml})$. C. albicans was prepared as 24 hours old culture, the number of $C$. albicans cells was counted for obtaining the required concentration $1 \times 10^{6}$ yeast cells $/ \mathrm{ml}$. Separated peripheral blood leucocytes were adjusted to a concentration of $2.5 \times 10^{6}$ viable cells $/ \mathrm{ml}$, then to each I ml volume of adjusted blood leucocytes C.albicians suspension was added, then incubated in an incubator $\left(\mathrm{CO}_{2} 5\right.$ $10 \%$ ) at $37{ }^{\circ} \mathrm{C}$ for one hour. Cover slips were stained with Giemsa stain. The phagocytic assay was calculated according to the following equations:

Phagocytic activity $=$ No. of Ingesting phagocytes $/$ total No. of phagocytes.

Phagocytic index = No. of ingested C. albicans cells / No. of Ingesting phagocytes.

\section{b- Measuring of hepatosomatic index (HSI):-}

At the end of experimental period, 5 fish from each group were dissected and the viscus was examined. The liver was weighed and HSI was calculated according to (Htun-hun, 1978).

HSI = weight of the liver/fish body weight. 


\section{c-Neutrophils glass- adhesion assay}

Neutrophils glass- adherent, using nitroblue tetrazolium assay, was determined according to Anderson et al. (1992). Briefly, one drop of heparinized blood sample was placed onto cover slip. The cover slips were incubated for 30 minutes at room temperature $\left(25^{\circ} \mathrm{C}\right)$ in humid chambers to allow the neutrophils to stick to the glass. Cover slips were gently washed with PBS (pH 7.4) and the cells were transferred to a microscope slide containing a $50 \mu \mathrm{l}$ drop of $0.2 \%$ filtrated NBT solution (Fluka Buchs, Co. Switzerland). The positive, dark-blue stained cells were counted under the microscope.

\section{d-Challenge test:-}

A total number of 25 fish (5 fish from each treatment) were injected I/P with the pathogenic A. hydrophila which kindly obtained from fish diseases department, animal health research institute $\left(0.3 \mathrm{ml}\right.$ of $10^{8}$ cells $\left./ \mathrm{ml}\right)$ according to Schaperclaus et al. (1992), the injected fishes were kept under observation for 14 day to record the mortality rate.

Mortality rate $\%=$ No. of death in specific period/ Total population during that period $\mathrm{x} 100$.

\section{6-Statistical analysis:-}

Duncan's Multiple Range Duncan (1955) was used to determine differences among means at significance level of 0.05. All statistics were run on the computer using the SPSS program (SPSS, 2004).

\section{RESULTS AND DISCUSSION}

\section{1- Clinical and Post mortem examination of O. niloticus:}

$O$. niloticus in group fed highly contaminated ration T1 suffered from loss of appetite, lethargy, loss of reflexes at the end of the experiment. El-Boshy et al. (2008) agreed with our findings as they stated that $\mathrm{AFB}_{1}$ intoxicated fish showed off feed, sluggish swimming, dark skin, loss of reflexes, increased mucus secretion, loss of scales and ascities .Internally, liver displayed pale coloration with patches of congestion and pin point hemorrhages.

Post examination presented in Figs $(1,2,3$ and 4$)$ revealed that $O$. niloticus in TI group which fed on high $\mathrm{AFB}_{1}$ diet exhibit some pathological lesion as enlarged hepatopancrease, enlarged gall bladder spleenomegaly, and empty intestinal tract.

Also it was observed that the intense of clinical signs increased with high $\mathrm{AFB}_{1}$ concentration and period of exposure. Similar pictures as spleen and the Kidneys appeared enlarged, congested and dark in color were noticed by (El-Boshy et al., 2008 and Halver, 1968). Chavez et al. (1994) reported that O. niloticus fingerlings were able to tolerate the immediate effect of aflatoxin but later the fish developed external and internal abnormalities. Liver of fish were abnormal enlargement and yellowing were reported by (Roberts, 1978 and $\mathrm{Wu}, 1998$ ). Also our results agreed with findings of Dimia et al. (2005) who mentioned that mycotoxins induce several disorders in fish organism; biochemical, functional, morphological and in more severe cases mortality.

\section{2- Growth performance and feed utilization of $O$. niloticus fed different AFB1} levels:

Data presented in (Table 1) showed that group $\mathrm{T} 4\left(\mathrm{AFB}_{1} 20 \mu \mathrm{g} / \mathrm{kg}\right) \mathrm{had}$ significantly higher growth parameters and feed utilization (ADG, TG, FW, SGR and RGR) and (FCR and FI) compared with $\mathrm{T} 1\left(\mathrm{AFB}_{1} 100 \mu \mathrm{g} / \mathrm{kg}\right)$. SR the same trend, T4 had significantly higher recorded SR. Our findings agreed with some experimental studies as Shehata et al. (2009) stated that aflatoxicosis in O. niloticus induced by fed 
on $3 \mathrm{mg} \mathrm{AFB}_{1}$ significantly $(\mathrm{P} \leq 0.05)$ decreased body weight gain, relative growth rate in comparison with these of control and also they mentioned that the mortality rate significantly $(\mathrm{P} \leq 0.05)$ increased $(53.33 \%$ versus $6.67 \%$ for the control) by $20 \mu \mathrm{g}$ $\mathrm{AFB}_{1}$. Also Roberts and Sommerville (1982) mentioned that in tilapia culture aflatoxicosis was a major cause of losses. Lovell (1991) explained low survival rate as aflatoxin caused damage of liver and other body organs which led to death. These findings could be due to disturbance in metabolic processes of carbohydrate, lipid and protein (Cheeke and Shull, 1985 and Devegowda et al., 1998). A contrast results were obtained by (Jantrarotai and Lovell, 1990) showed that there was no significant reduction in weight gains or histopathological findings in catfish exposed to a wide range of $\mathrm{AFB}_{1}$ concentrations in diets (ranged from 100 to 2,154ppb $\mathrm{AFB}_{1}$ ).

Table 1: Mean $\pm \mathrm{SE}$ of growth performance parameters and survival rate of $O$. niloticus exposed to different levels of $\mathrm{AFB}_{1}$.

\begin{tabular}{l|l|l|l|l|l|l|l|l|l|l|}
\hline Item & IW & FW & ADG & TG & FCR & FI & SGR & RGR & SR \\
\hline T1 & $\mathbf{2 3}$ & $\mathbf{4 5 . 6}$ & $\mathbf{0 . 2 7}$ & $\mathbf{2 2 . 7}$ & $\mathbf{5 . 5 7}$ & $\mathbf{1 2 4}$ & $\mathbf{0 . 8 2}$ & $\mathbf{9 9 . 5}$ & \\
& $\pm \mathbf{0 . 7}$ & $\pm \mathbf{1 . 5}$ & $\pm \mathbf{0 . 0 2 6}$ & $\pm \mathbf{2 . 2}$ & $\pm \mathbf{0 . 4}$ & $\pm \mathbf{3 . 4}$ & $\pm \mathbf{0 . 0 7 7}$ & $\pm \mathbf{1 2 . 6}$ & $\mathbf{8 0}$ \\
\hline T4 & $\mathbf{2 3 . 8 7}$ & $\mathbf{7 8 . 7}$ & $\mathbf{0 . 6 5}$ & $\mathbf{5 4 . 9}$ & $\mathbf{3 . 4}$ & $\mathbf{1 8 8}$ & $\mathbf{1 . 4 2}$ & $\mathbf{2 2 9 . 6}$ & $\mathbf{9 0}$ \\
& $\pm \mathbf{0 . 5}$ & $\pm \mathbf{3 . 6}$ & $\pm \mathbf{0 . 0 3 7}$ & $\pm \mathbf{3 . 1}$ & $\pm \mathbf{0 . 1 2}$ & $\pm \mathbf{9 . 2 0}$ & $\pm \mathbf{0 . 3}$ & $\pm \mathbf{8 . 3}$ & \\
\hline Sig & $\mathbf{0 . 3 8}$ & $\mathbf{0 . 0 0 1}$ & $\mathbf{0 . 0 0 1}$ & $\mathbf{0 . 0 0 1}$ & $\mathbf{0 . 0 0 8}$ & $\mathbf{0 . 0 0 3}$ & $\mathbf{0 . 0 0 2}$ & $\mathbf{0 . 0 0 1}$ & - \\
\hline F value & $\mathbf{0 . 9 8 5}$ & $\mathbf{7 0 . 7 2}$ & $\mathbf{7 0 . 7 2}$ & $\mathbf{7 0 . 7 2}^{* *}$ & $\mathbf{2 3 . 2 7}^{* *}$ & $\mathbf{4 2 . 3 1}^{* *}$ & $\mathbf{5 3 . 0 3}^{* *}$ & $\mathbf{7 4 . 3 2}^{* *}$ & - \\
\hline
\end{tabular}

\section{3- Haemogram picture and differential leukogram of $O$. niloticus fed different $\mathrm{AFB}_{1}$ levels:}

The application of haematological have proved to be valuable for fishery biolo01gists in assessing the health of fish and monitoring stress responses either due to fluctuations in environmental condition or due to sub lethal concentration of pollutants. Haematology concerns mainly investigations on cells present in the blood, RBCs, Hb, PCV, WBC, MCH, MCHC and MCV (Kapila, 1999). Findings presented in Table (2) showed that erthrogram of T1had significantly had lower values comparing with $\mathrm{T} 4$ indicating that $\mathrm{AFB}_{1}$ at concentration $100 \mu \mathrm{g} / \mathrm{kg}$ could cause an adverse effect on health status and $O$. niloticus may suffer from anemic condition as it obvious from results of RBCs, Hb, PCV, MCV, $\mathrm{MCH}$ and $\mathrm{MCHC}$ 1.7, 4.6, 17.7, 104.5, 27.4 and 26.4 respectively. Lowering the $\mathrm{AFB}_{1}$ concentration to $20 \mu \mathrm{g} / \mathrm{kg}$ (T2) for 10 days didn't significantly improve $O$. niloticus adverse condition while treatment by biological antitoxin plus lowering the $\mathrm{AFB}_{1}$ concentration to $20 \mu \mathrm{g} / \mathrm{kg}$ would improve significantly the health condition as RBCs, Hb, PCV, MCV, MCH and MCHC 2.32, 8.9, 32.7, 139.7, 38.3 and 27.5. The most improved health status had recorded by $\mathrm{T} 5$ as $O$. niloticus had fed on diet contaminated with $\mathrm{AFB}_{1} 20 \mu \mathrm{g} / \mathrm{kg}$ and treated by biological antitoxin. These results could be explained by the findings of Dimia et al. (2005) who stated that biochemical alterations and metabolism disturbance lead to changes in nutrient resorption and primary brings to cell and organ alterations. Our findings agreed with those obtained by (Hussein et al., 2000 and Rizkalla et al., 1997) as they recorded anemia in O. niloticus fed on ration supplemented $\mathrm{AFB}_{1}$. Neutrophilia, and lymphopenia are the main leukocytic pictures in acute stress of teleost fish (Robert 2001). Data concerning WBCs agreed with

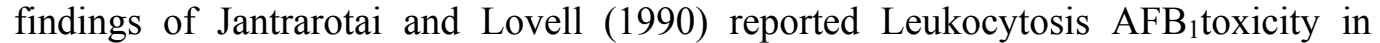
channel catfish Ictularus punctatus fed $10 \mathrm{mg} \mathrm{AFB} / \mathrm{Kg}$ diet. Different findings were obtained by Hussein et al., (2000) who mentioned that Oreochromis species exposed to $50 \mu \mathrm{g}$ crude $\mathrm{AFB}_{1} / \mathrm{Kg}$ feed for 22 weeks, $3 \mathrm{mg} \mathrm{AFB}_{1} / \mathrm{Kg}$ diet for 90 days and 1.0 
$\mu \mathrm{g} \mathrm{AFB}_{1} / \mathrm{Kg} \mathrm{BW}$ for 10 days, respectively suffered from leukopenia these differences could be explained by the different durations. Similar findings had observed by Selim et al. (2013) who stated that the total erythrocyte count, hemoglobin content and total leukocyte count were significantly decreased after $\mathrm{AFB}_{1}$ exposure for 6,8 and 10 weeks, respectively.

Table 2: Mean \pm SE of complete blood picture of $O$. niloticus exposed to different levels of $\mathrm{AFB}_{1}$.

\begin{tabular}{|c|c|c|c|c|c|}
\hline Item & $\mathrm{T} 1$ & $\mathrm{~T} 2$ & T3 & $\mathrm{T} 4$ & T5 \\
\hline RBCs $\times 10^{6}$ & $1.7^{\mathrm{c}} \pm 0.1$ & $1.97^{\mathrm{bc}} \pm 0.1$ & $2.32^{\mathrm{ab}} \pm 0.22$ & $2.58^{\mathrm{a}} \pm 0.15$ & $2.8^{\mathrm{a}} \pm 0.26$ \\
\hline $\mathrm{Hb}$ g/dl & $4.6^{c} \pm 0.14$ & $6.7^{\mathrm{c}} \pm 0.33$ & $8.9^{b} \pm 1.16$ & $10.1^{\mathrm{ab}} \pm 0.52$ & $11.2^{\mathrm{a}} \pm 0.73$ \\
\hline $\mathrm{PCV} \%$ & $17.7^{\mathrm{c}} \pm 1.2$ & $25 b^{c} \pm 2.31$ & $32.7^{\mathrm{ab}} \pm 4.7$ & $37.7^{\mathrm{a}} \pm 1.2$ & $38.3^{\mathrm{a}} \pm 1.8$ \\
\hline $\mathrm{MCV} \mathrm{Fl}$ & $104.5^{\mathrm{b}} \pm 6.4$ & $126.9^{\mathrm{ab}} \pm 9.1$ & $139.7^{\mathrm{a}} \pm 8.3$ & $146.7^{\mathrm{a}} \pm 4$ & $138.3^{\mathrm{a}} \pm 7.21$ \\
\hline $\mathrm{MCH} \mathrm{Pg}$ & $27.4^{\mathrm{c}} \pm 0.95$ & $33.9^{b} \pm 0.57$ & $38.3^{\mathrm{a}} \pm 1.4$ & $39.1^{\mathrm{a}} \pm 0.23$ & $40.15^{\mathrm{a}} \pm 1.7$ \\
\hline $\mathrm{MCHC} \%$ & $26.4^{\mathrm{a}} \pm 1.8$ & $26.9^{\mathrm{a}} \pm 1.4$ & $27.5^{\mathrm{a}} \pm 1.6$ & $26.7^{\mathrm{a}} \pm 0.56$ & $29.9^{\mathrm{a}} \pm 1.5$ \\
\hline WBCs $10^{3}$ & $44^{\mathrm{c}} \pm 2.3$ & $52^{b c} \pm 1.7$ & $59^{\mathrm{ab}} \pm 3.5$ & $61.7^{\mathrm{ab}} \pm 4.8$ & $68.3^{\mathrm{a}} \pm 2.4$ \\
\hline Het $\%$ & $25.8^{\mathrm{a}} \pm 0.5$ & $23.7^{\mathrm{b}} \pm 0.5$ & $23.3^{\mathrm{b}} \pm 0.17$ & $22.2^{\mathrm{b}} \pm 0.7$ & $19.5^{\mathrm{c}} \pm 0.64$ \\
\hline Mono \% & $5.5^{\mathrm{a}} \pm 0.2$ & $4.6^{\mathrm{b}} \pm 0.16$ & $4.53^{b} \pm 0.18$ & $4.3^{\mathrm{b}} \pm 0.22$ & $3.57^{\mathrm{c}} \pm 0.2$ \\
\hline Esino \% & $2.7^{\mathrm{a}} \pm 0.08$ & $2.5^{\mathrm{b}} \pm 0.1$ & $2.16^{\mathrm{c}} \pm 0.12$ & $2.23^{b c} \pm 0.1$ & $2.1^{\mathrm{c}} \pm 0.1$ \\
\hline Baso \% & $0.33 \pm 0.3$ & $0.33 \pm 0.3$ & $0.33 \pm 0.3$ & $0.33 \pm 0.3$ & 0.0 \\
\hline Lympho \% & $65.1^{\mathrm{d}} \pm 0.95$ & $68.8^{\mathrm{c}} \pm 1.45$ & $69.7^{\mathrm{bc}} \pm 1.1$ & $70.5^{\mathrm{b}} \pm 0.5$ & $74^{\mathrm{a}} \pm 1.2$ \\
\hline
\end{tabular}

Group with different letter within the same column are significantly different at $\mathbf{P} \leq \mathbf{0 . 0 5}$.

\section{4- Liver enzymes, kidneys enzymes and serum total protein examination of $O$.} niloticus fed different $\mathrm{AFB}_{1}$ levels:

Serological tests are important diagnostic tools in fish diseases investigation as Kapila (1999) stated that serology deals with the constituents in the fluid part of blood such as protein, enzymes, minerals, carbohydrates pigments, hormones, immune bodies etc. Liver enzymes ALT, AST and ALP activity in serum of O. niloticus presented in Table (3) emphasized that $O$. niloticus fed on high $\mathrm{AFB}_{1}$ concentration $100 \mu \mathrm{g} / \mathrm{kg} \mathrm{T} 1 \mathrm{had}$ increased significantly comparing with T4 indicating liver damage and impairment of function as they had reached 32.3, 137.7 and 28.6 respectively. An improvement was recorded by lowering the $\mathrm{AFB}_{1}$ to $20 \mu \mathrm{g} / \mathrm{kg}$ and lowering the $\mathrm{AFB}_{1}$ to $20 \mu \mathrm{g} / \mathrm{kg}$ plus biological treatment as ALT, AST and alkaline phosphatase had decreased significantly. Creatinine and urea significantly affected by high level $\mathrm{AFB}_{1}$ indicating damages in kidneys tissue.

Table 3: Mean \pm SE of liver enzymes, kidneys enzymes and serum total protein of O. niloticus exposed to different levels of $\mathrm{AFB}_{1}$.

\begin{tabular}{|c|c|c|c|c|c|}
\hline Item & $\mathrm{T} 1$ & $\mathrm{~T} 2$ & T3 & $\mathrm{T} 4$ & T5 \\
\hline ALT & $32.3^{\mathrm{a}} \pm 1.86$ & $27.3^{\mathrm{ab}} \pm 1.45$ & $21^{\mathrm{c}} \pm 2.8$ & $24^{\mathrm{bc}} \pm 1.53$ & $23.3^{b c} \pm 1.2$ \\
\hline AST & $137.7^{\mathrm{a}} \pm 2.8$ & $132^{\mathrm{a}} \pm 1.5$ & $115.3^{\mathrm{b}} \pm 3.18$ & $115.3^{\mathrm{b}} \pm 2.4$ & $104.7^{\mathrm{b}} \pm 7.1$ \\
\hline Urea (mg/dl) & $5.1^{\mathrm{a}} \pm 0.05$ & $3.47^{\mathrm{b}} \pm 0.9$ & $4.1^{\mathrm{ab}} \pm 0.6$ & $3.77^{\mathrm{ab}} \pm 0.09$ & $2.9^{\mathrm{b}} \pm 0.06$ \\
\hline Creatinine (mg/dl) & $1.03^{\mathrm{a}} \pm 0.03$ & $0.89^{b} \pm 0.02$ & $0.83^{b c} \pm 0.01$ & $0.79^{c} \pm 0.02$ & $0.8^{\mathrm{c}} \pm 0.06$ \\
\hline ALP (mg/dl) & $28.6^{a} \pm 1.7$ & $26.8^{\mathrm{a}} \pm 1.3$ & $20.1^{b} \pm 1.25$ & $20.6^{\mathrm{b}} \pm 1.6$ & $16.9^{b} \pm 0.5$ \\
\hline HSI & $4.27^{\mathrm{a}} \pm 0.12$ & $3.27^{b} \pm 0.12$ & $2.9^{\mathrm{bc}} \pm 0.18$ & $2.36^{\mathrm{c}} \pm 0.3$ & $2.16^{\mathrm{c}} \pm 0.37$ \\
\hline $\mathrm{TP}(\mathrm{g} / \mathrm{dl})$ & $2.8^{\mathrm{c}} \pm 0.22$ & $3.4^{\mathrm{bc}} \pm 0.36$ & $4.3^{\mathrm{ab}} \pm 0.5$ & $4.5^{\mathrm{ab}} \pm 0.14$ & $5.1^{\mathrm{a}} \pm 0.5$ \\
\hline $\mathrm{A}(\mathrm{g} / \mathrm{dl})$ & $1.25 \pm 0.18$ & $1.3 \pm 0.1$ & $1.23 \pm 0.13$ & $1.3 \pm 0.12$ & $1.15 \pm 0.1$ \\
\hline Globulin $(\mathrm{g} / \mathrm{dl})$ & $1.6^{\mathrm{b}} \pm 0.12$ & $2.1^{\mathrm{b}} \pm 0.3$ & $3.1^{\mathrm{a}} \pm 0.3$ & $3.24^{\mathrm{a}} \pm 0.24$ & $3.9^{\mathrm{a}} \pm 0.4$ \\
\hline Alpha (g/dl) & $0.42^{\mathrm{c}} \pm 0.04$ & $0.52^{\mathrm{bc}} \pm 0.16$ & $0.8^{\mathrm{ab}} \pm 0.1$ & $0.88^{\mathrm{a}} \pm 0.1$ & $0.72^{\mathrm{bc}} \pm 0.04$ \\
\hline Beta $(\mathrm{g} / \mathrm{dl})$ & $0.34^{\mathrm{b}} \pm 0.05$ & $0.37^{b} \pm 0.08$ & $0.9^{\mathrm{a}} \pm 0.14$ & $0.97^{\mathrm{a}} \pm 0.1$ & $1.12^{\mathrm{a}} \pm 0.14$ \\
\hline$(\mathrm{g} / \mathrm{dl})$ & $0.83^{\mathrm{c}} \pm 0.04$ & $1.2^{\mathrm{bc}} \pm 0.14$ & $1.37^{\mathrm{ab}} \pm 0.1$ & $1.36^{\mathrm{ab}} \pm 0.2$ & $1.75^{\mathrm{a}} \pm 0.13$ \\
\hline $\mathrm{A} / \mathrm{G}$ & $78.9^{b} \pm 1.8$ & $68.1^{b} \pm 13.9$ & $41^{\mathrm{b}} \pm 2.17$ & $41^{\mathrm{a}} \pm 5.5$ & $29.1^{\mathrm{a}} \pm 1.7$ \\
\hline
\end{tabular}

Group with different letter within the same column are significantly different at $\mathrm{P} \leq 0.05 . \mathrm{A} / \mathrm{G}=\mathrm{Albumin}$ Globulin ratio. 
Creatinine and urea had the same trend of liver enzymes as it had improved significantly by lowering $\mathrm{AFB}_{1}$ concentration and addition of biological antitoxin. Our results could be explained by findings of Kapila (1999) who stated that AST, ALT and alkaline phosphatase enzymes are released into the circulatory system (serum) by cellular damage or destruction. Liver is rich in AST and ALT and changes in plasma levels of these enzymes may be indicative of liver dysfunction. Alkaline phosphatase is involved in membrane transport and is a good indicator of stress in biological systems (Verma et al. 1980). Findings of El-Boshy et al. (2008) had agreed with our results as they stated that the elevation of ALT and AST activities in O. niloticus caused as a result of supplementation diet with $\mathrm{AFB}_{1}$ could be attributed to hepatic injury. Also Pepeljnjak et al. (2003) agreed with these findings as they noticed an elevation in liver enzymes of Cyprinus carpio fed $5.0 \mathrm{mg} \mathrm{AFB} / 1 \mathrm{~kg}$ body weight for 42 days. Shehata et al. (2009) and Abd El-Baki et al. (2002) mentioned that tested blood parameters (total protein, albumin, globulin, AST and ALT) of O. niloticus fed on diet contaminated with $\mathrm{AFB}_{1}$ were decreased. Our results also agreed with those obtained with Selim et al. (2013) who had experimented hydrated sodium calcium aluminosilicates, Saccharomyces cerevisiae and an esterified glucomannan, against feed contaminated with contained $200 \mu \mathrm{g} / \mathrm{kg}$ (ppb) $\mathrm{AFB}_{1}$ and stated that O. niloticus showed reduction of the survivability, total weight gain, average daily gain and specific growth rate, evident as early as the second week of exposure, also they mentioned that prolonged administration of $\mathrm{AFB}_{1}$ led to significant increases in serum ALT, AST and creatinine activity. Determination of blood creatinine is routinely used as an index of renal function (Melby and Altman, 1974). The gills is the main organ of excretion of urea rather the kidney (Stoskoph, 1993) so the elevation of urea could indicate dysfunction of the gills of $O$. niloticus which fed on $\mathrm{AFB}_{1}$ supplemented diet (Hussein et al., 2000 and El-Boshy et al., 2008). An elevation of serum creatinine might be attributed to the renal damage that had induced renal impairment. In contrast of our results El-Boshy et al. (2008) observed insignificant creatinine increased level in $\mathrm{AFB}_{1}$ treated group.

Serum protein concentrations can be used to monitor disease progress and general physiological status, as total protein levels tend to drop in diseased states. Sequential total protein analysis provides quantitative evidence of disease progression (Searcy et al., 1964). The decrease in the serum protein level could be correlated with severe damage of hepatocytes as indicated by histopathological studies. Similar observations were observed in Nile tilapia by (Saber, 1995 and Roberts and Sommerville, 1982). Total protein, albumin, globuline, albumin / globuline ratio and globulin fraction had the same trend of liver enzymes. Total protein and albumin concentrations were decreased in fresh water fishes fed on diet contaminated with $\mathrm{AFB}_{1}$ and this decline could be explained that mycotoxins had caused a hepatotoxic condition that resulted in impairing protein synthesis and/or liver disorder (Sahoo et al., 1998, Buhler et al., 2000, Pepeljnjak et al., 2003 and El-Boshy et al., 2008). Decrease in total protein and albumin may be attributed to aflatoxin caused hepatotoxicity that interacted with protein synthesis (Srivastava, 1984).

5- Immune status of $O$. niloticus fed different $\mathrm{AFB}_{1}$ levels:

Immune status of examined $O$. niloticus had been tested by measuring phagocytic activities, neutrophil glass adhesion test and challenge against $A$. hydrophilla. Data presented in Table (4) indicated that $O$. niloticus fed highly contaminated diet $\mathrm{T} 1$ will exhibit lower immunological status and lowering $\mathrm{AFB}_{1}$ concentration plus biological antitoxin treatment $\mathrm{T} 3$ could improve the immune status. The AFB1 had an immune-suppression; this reduction could be a result of the toxic 
effect of aflatoxins on the hematopoietic tissues (Ghosh et al., 1990). Glass-adherent NBT-positive cells which indicated the suppression of non-specific immunity level in O. niloticus Sahoo and Mukherjee (2001)agreed with the results of our experiment observed that decreased glass adhesion NBT-positive neutrophils of Labeo rohita exposed to $\mathrm{AFB}_{1}$. The macrophage phagocytic index was significantly decreased in AFB1treated groups suppressed the macrophage phagocytic activity and macromolecular synthesis of macrophages as reported in O. niloticus (El-Enbaawy et al., 1994 and El-Boshy et al., 2008). Our results could be explained by those obtained by Rodriguez-Cervantes et al. (2010) as they stated that aflatoxins generate a longterm dysfunction in the specific and non-specific immune response of aquatic organisms. Also Selim et al. (2013) mentioned that $\mathrm{AFB}_{1}$ reduced the serum levels of total protein, albumin and globulin and after challenge with A. hydrophila, $\mathrm{AFB}_{1}$ produced a low level of agglutinating antibody titer and a scant relative level of protection. S. cerevisiae and esterified glucomannan effectively improved $\mathrm{AFB}_{1}$ toxicity.

Table 4: Mean \pm SE of phagocytic activities and neutrophils glass adhesion of $O$. niloticus exposed to different levels of $\mathrm{AFB}_{1}$.

\begin{tabular}{|c|c|c|c|c|c|c|}
\hline \multicolumn{2}{|l|}{ Item } & $\mathrm{T} 1$ & $\mathrm{~T} 2$ & T3 & $\mathrm{T} 4$ & T5 \\
\hline \multirow[t]{2}{*}{ Phagocytic } & index & $\begin{array}{l}0.67^{\mathrm{c}} \\
\pm 0.33\end{array}$ & $\begin{array}{l}0.87^{\mathrm{bc}} \\
\pm 0.44\end{array}$ & $\begin{array}{l}1.7^{\mathrm{bc}} \\
\pm 0.38\end{array}$ & $\begin{array}{l}1.8^{\mathrm{b}} \\
\pm 0.35\end{array}$ & $\begin{array}{l}3.1^{\mathrm{a}} \\
\pm 0.21\end{array}$ \\
\hline & assay & $\begin{array}{l}16.7^{\mathrm{c}} \\
\pm 0.8\end{array}$ & $\begin{array}{l}20^{\mathrm{bc}} \\
\pm 1.2\end{array}$ & $\begin{array}{l}48.3^{\mathrm{ab}} \\
\pm 0.78\end{array}$ & $\begin{array}{l}43.3^{b} \\
\pm 3.3\end{array}$ & $\begin{array}{l}61.7^{\mathrm{a}} \\
\pm 6\end{array}$ \\
\hline \multicolumn{2}{|c|}{ Neutrophils glass } & $\begin{array}{l}6^{\mathrm{d}} \\
\pm 0.6\end{array}$ & $\begin{array}{l}7^{7 d} \\
\pm 0.3\end{array}$ & $\begin{array}{l}10^{\mathrm{c}} \\
\pm 1.12\end{array}$ & $\begin{array}{l}15.3^{b} \\
\pm 0.6\end{array}$ & $\begin{array}{l}17.3^{\mathrm{a}} \\
\pm 0.3\end{array}$ \\
\hline \multicolumn{2}{|c|}{ Challenge test MR\% } & 100 & 100 & 60 & 40 & 20 \\
\hline
\end{tabular}

Group with different letter within the same raw are significantly different at $\mathrm{P} \leq 0.05$.

\section{CONCLUSION}

$\mathrm{AFB}_{1}$ had an adverse effect on immune status and liver function of $O$. niloticus leading to decrease feed utilization and increase susceptibility to infectious diseases. These bad effects could be lowered by decrease the level of AFB1 and use of biological antitoxin.

\section{REFERENCE}

Abd El-Baki S.M.; Nowar, M.S.; Hassona, E.A.; Bassuny, S.M. and Shehata, S. A. (2002). Clays in animal nutrition: 10 - Detoxification of aflatoxin B1 by tafla clay in rabbit feeds. $3^{\text {rd }}$ Sci. Con. on Rabbit Production in Hot Climates, 8-11 Oct., pp. 557-567.

Abdelhamid, A.M. and Mahmoud, K.I. (1996). Elimination or adsorption of aflatoxin from poultry feedstuffs. Proc. Conf. Foodborne contamination \& Egyptian's Health, Mansoura Univ., 26-27 Nov., pp. 61-69.

Ahmad, M.A.; Shamsuddin, Z.A. and Khan, B.A., (1996). Elimination of naturally occurring aflatoxins in cottonseed meal. Pak. J. Sci. Ind. Res., 39: 183-185.

Amlacher, E. (1970). Text book of fish disease. T.E.S. publication, New Jersey, USA, pp. 117-135.

Anderson, D.P.: Moritomo, T. and Grooth, R. (1992). Neutrophil glass adherence nitroblue tetrazolium assay gives early indication of immunization effectiveness in rainbow trout. Veterinary Immunology \& Immunopathology, 30: 419-429. 
Buhler, D.R.; Miranda, C.L.; Henderson, M.C.; Yang, Y.H.; Lee, S.J. and WangBuhler, J.L. (2000). Effects of 17beta-estradiol and testosterone on hepatic mRNA/protein levels and catalytic activities of CYP2M1, CYP2K1, and CYP3A27 in rainbow trout Oncorhynchus mykiss. Toxico. Appl. Pharmacol., 168(2):91-101.

Castell, J. D. and Tiews, K. (1980). Report of the EIFAC. IUNS and ICES working group on the standraization of methodology in fish nutration research. Hamburg, Federal Republic of Germany, EIFAC Technology, 36: 24.

Chavez, S.; Martinez, P.; Osorio, M.; Palacios, C. A. M. and Mareno, I.O. (1994). Pathological effects of feeding young Oreochromis niloticus diets supplemented with different levels of aflatoxin. Aquacult., 127 (1): 49-61.

Cheeke, P.K. and Shull, L.R. (1985). Natural toxicants in Feeds and Poisonous Plants. Avi Publishing Company. ING, Westport, Connecticut.

Dacie, J. V. and lewis, S.M. (1975). (Practical Haematology.) London, Churchill. Livingstone.

Devegowda,G.; Raju, M.V.L.N.; Afazali, N. and Swamy, H.V.L.N. (1998). Mycotoxins picture worldwide: Novel solutions for their counteraction. In T.P. Lyons and K.A. Jacques (Eds.) Biotechnology in the Feed Industry, pp. 241255. Proc. of Alltech's 14, the Annual Symposium, Nottingham, U.K.

Diekman, D.A. and Green, M.L. (1992). Mycotoxins and reproduction in domestic livestock. J. Anim. Sci., 70:1615-1627.

Dimia, D.J.; Jeremia, S.; Nesia, K. and Radosavljevia, V. (2005). The influence of mycotoxins in food on fish health status. The first scientific meeting Mycology, mycotoxicology and mycoses., pp. 73-79.

Doumas, B.T.; Waston, W.A. and Biggs, H.G. (1971): Albumin standards and the measurements of serum albumin with Bromocresol Green. Clinica Chimica Acta, 31: 87-96.

Duncan, D.B. (1955). Multiple range and multiple "F" test. Biometrics, 11:10.

El-Boshy, M.E.; El-Ashram, A.M.M. and Nadia, A. Abd El-Ghany (2008). Effect of dietary beta-1, 3 glucan on immunomodulation on diseased $O$ reochromis niloticus experimentally infected with aflatoxin B1.

El-Enbaawy, M.; Adel, M. S.; Marzouk, M. and Salem, A. A. (1994). The effects of acute and chronic aflatoxicosis on the immune functions of Oreochromis niloticus in Egypt. Vet. Med. J. Giza., 42:47-52.

Eppley, R. M. (1968). Screening method for zearalenone, aflatoxin and ochratoxin. J. AOAC, 51 (1): 74-78.

Faulmann, E.; Cuchens, M.A.; Lobb, C.K.; Miller, N.W. and Clem, L.W. (1983). Culture system for studying in vitro mitogenic responses of channel catfish lymphocytes transactions of the American fisheries Society., 112: 673-679.

Ghosh, R.G.; Ghauhan, H.V.S. and Roy, S. (1990). Immunosuppression in broilers under experimental aflatoxicosis. Br. Vet. J., 116: 457-462.

Glick, B. (1968). Serum protien electrophoresis pattern in acrylamide gel. Pattern from normal and bursa less birds. Poult. Sci., 47:807-814.

Hagazy, E. (1988). Treatment of Rations Affected with Aflatoxin and Possibility of its Safety Use. Ph.D.V.S., Fac. of Vet. Med. Cairo Univ.

Halver, J.E. (1968). Aflatoxins and trout hepatoma. Bull. Int. Epiz., (7-8) 1219 1278.

Hassan, S.A.; Amal, A.A. Abo-Hagar; El-Deeb, A.A. and Akila, S. Hamza (2002). Study on aflatoxin and its pathogenic fungi in row and rosted peanut from some 
market in Egypt. Proc. $2^{\text {nd }}$ Conf. Food born Contamination and Egyptian's Health, 23-24 April, Al- Mansoura Univ., Egypt.

Henry, R.J. (1974). Clinical chemistry, principles and technical. $2^{\text {nd }}$ Edition, Harper and Row, P525.

Hong-jun, L. and Xiao-ting, Z. (2005). Effects of Nosiheptide on Immunity Function in Broilers. Chinese Journal of Veterinary, 05-030.

Htun-han, M. (1978). The reproductive biology of the dab Limanda limanda (L) in the North Sea; gonadosomatic Index; Hepatosomatic Index and condition factor. J. Fish Biol., 13: 369-378.

Hussein, S.Y.; Mekkawy, I. A.; Moktar, Z. Z. and Mubarak, M. (2000). Protective effect of Nigella sativa seed against aflatoxicosis in Oreochromis niloticus. Mycotoxin Conference, Mycotoxins, and Environmental "Poland, Bydgoszez, 25-27: 109-130.

Jantrarotai, I. V. and Lovell, R. T. (1990). Subchronic toxicity of dietary aflatoxin B to channel catfish. J of Aquatic Anim. Health, 2: 248-254.

Kapila, R. (1999). Biochemical status of cold water fishes, Bulletin No: 3, National research center on cold water fisheries, U.P. (India).

Kawahara, E. T.; Lieda, K. N. and Nomura, S. M. (1991). In vitro phagocytic activity of white-spotted char blood cells after injection with Aeromonas salmonicida extra cellular products. Gyobyu KenKyu, 26: 213-214.

Lovell, R.T. (1991). Mycotoxins in fish feeds. Feed Mangement, 42 (11): 42-44.

Lucky, Z. (1977). Methods for Diagnosis of Fish Disease. Amerind Publishing Co. New York.

Maurer, R. (1971). Disc electrophoresis and related technique of polyacrylamide gel electrophoresis. Water de Grugter Berlin, New York.

Melby, E. C. and Altman, N. H. (1974). Handbook of laboratory animal Science, Vol II. CRC. Press, INC Ohio, 365 -391.

Patton, C. J. and Crouch, S. R. (1977): Anal. Chem., 49: 464- 469.

Pepeljnjak, S.; Petrinec, Z.; Kovacic, S. and Segvic, M. (2003). Screening toxicity study in young carp Cyprinus carpio L. on feed amended with fumonisin $\mathrm{B}_{1}$. Mycopathologia., 156(2):139-45.

Rec, G.S. (1972). Determination of alkaline phosphatase. J. Clin. Chem. Clin. Biochem. 10:182.

Reitman, S. and Frankel, S. (1957). Determination of AST and ALT in serum. American Journal of Clinical Pathology, 28: 56-68.

Rizkalla, E.H.. Zahra, M. H.; Deab, A. and Farag, M. F. (1997). Hematological responsiveness of Oreochromis aureus to dietary aflatoxins contamination and the role of selenium and vitamine E. Alex. J. Vet. Sci., 13 (4): 423-438.

Roberts, R.J. (1978). Fish Pathology. Casell Ltd., London.

Roberts, R.J. (2001). Fish Pathology. $3^{\text {rd }}$ edition, W. B. Sauders, U. K.

Roberts, R.J. and Sommerville, C. (1982). Diseases of Tilapias. In: Pullin R.S.V. and R.H. Lowe-McConnel, (Eds.), the Biology and Culture of Tilapia. ICLARM Conference Proceeding, Manila, Philippines, pp. 247-263.

Rodriguez-Cervantes, C.H.; Giron-Perez, M.I.; Robledo-Marenco M.L.; Marin S.; Velazquez-Fernandez J.B.; Medina-Diaz I.M.; Rojas-Garcia, A.E. and Ramos, A.J. (2010). Aflatoxin B1 and its toxic effects on immune response of teleost fishes: a review. World Mycotoxin J, 3(2):193-199.

Saber, N.A. (1995). Depression of protein synthesis in tilapia by aflatoxin, Bull. Nat. Inst. Oceanogr. Egypt., 21(2): 431-638. 
Sahoo, P. K. and Mukherjee, S.C. (2001). Immunosuppressive effects of aflatoxin B1 in Indian major carp (Labeo rohita). Comparative Immunology, Microbiology and Infectious Diseases., 24: 143-149.

Sahoo, P.K.; Mukherjee, S.C.; Jain, A.K. and Mukherjee, A. (1998). Light and ultrastructural alterations in liver of Labeo rohita due to acute and subchronic aflatoxicosis (abstract). In: National Symposium on Advances in Diagnostic Veterinary Pathology, KAU, Thrissur, India.

Schaperclaus, W.; Kulow, H. and schreckenbach, K. (1992). Fish diseases. A.A. Balkema, Rotterdam, the Netherlands. Science, 142: 676-678.

Searcy, R. L.; Ujihara, I.; Hayashi, S. and Berk, J. E. (1964). An intrinsic disparity between amyloclastic and saccharogenic estimations of human serum isoamylase activities, Clin. Chem. Acta., 9: 505.

Selim, K.M.; El-hofy, H. and Khalil, R.H. (2013). The efficacy of three mycotoxin adsorbents to alleviate aflatoxin B1-induced toxicity in O. niloticus. Aquaculutre Int. Pub Springer online.

Shehata S.A.; Mohamed, M.S. and Mohamed, G.A. (2003). Reducing the toxicity of aflatoxin B1 by different adsorbents in fish. J. Agric. Sci. Mansoura Univ., 28 (10): 7157-7167.

Shehata, S.A.; El-Melegy, K.H.M. and Ebrahim, M.S. (2009). Toxicity Reduction of Aflatoxin B1 by Vitamin C in Fish. J. Arabian Aquacult. Society., 4 (2):73-86.

SPSS (2004). "Statistical and package for social science, SPSS for windows release14.0.0, 19 June, 2004." Standard version, copyright SPSS Inc., 19892004.

Srivastava, A.K. (1984). Pharmaco kinetics and therapeutic evaluation of oximes buffalo calves. Ph.D. Thesis, Punjab Agric. Univ., Ludhiana, India.

Stoskoph, M.K. (1993). Fish Medicine. PP,116,128,129.W.B. Saunders Company.

Tacon, A. (1987). The nutrition and feeding of farmed fish and shrimp a training manual. V61. 1. The essential nutrients FAO., PP. 117-130.

Verma, S.R.; Rani, S. and Dalela, R.C. (1980). Effects of phenol and dinitrophenol on acid and alkaline phosphatase activities in tissues of a fish Notopterus, Arch. Environ. Conta. In. Toxico1., 9: 451-459.

Weichselbaum, T.E. (1946). Determination of total proteins. Am. J. Clin. Pathol., 7: 40.

Wolf, H. and Jackson, E.W. (1963). Heptomas in rainbow trout: descriptive and experimental epidemiology.

Wu, F.C. (1998). Retention of diet-related mycotoxins in tissues of channel catfish. (http://www.egsz.or/BilogicalCurrentContent/Zoology?Comparative\%2Physiolo gy/TOXICOLOGY.html).

Zaki, M.S., Nevin, E. Sharaf, Hend, Rashad, Susan, O. Mostafa and Olfat, M. Fawzi (2008). Diminution of Aflatoxicosis in Tilapia nilotica fish by dietary supplementation with Fix in toxin and Nigella sativa oil. American-Eurasian J. Agric. \& Environ. Sci., 3 (2): 211-215. 


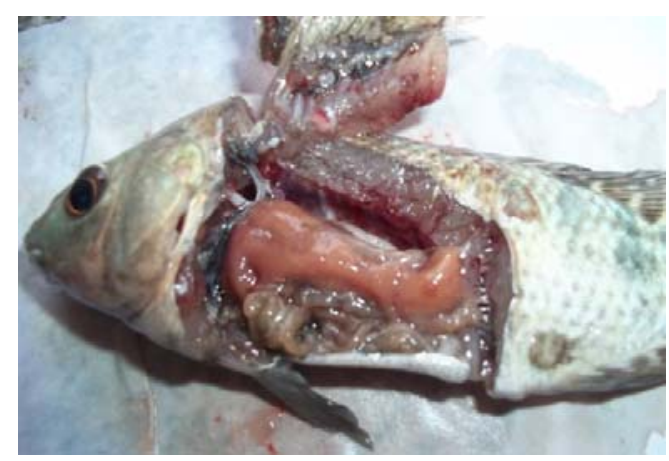

(1)

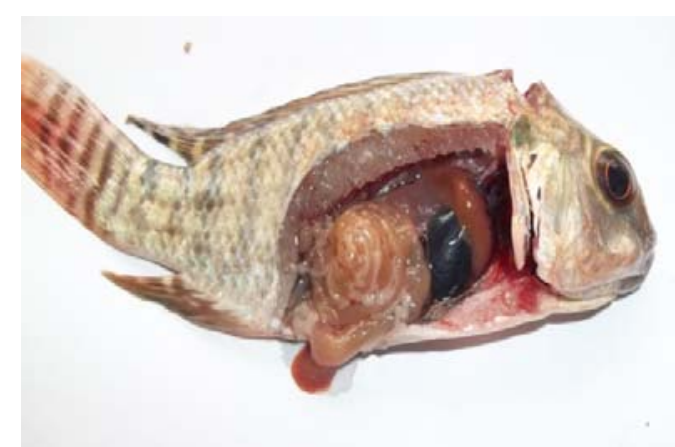

(3)

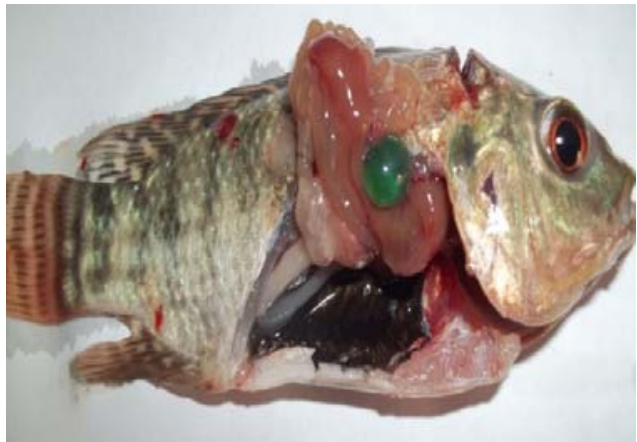

(2)

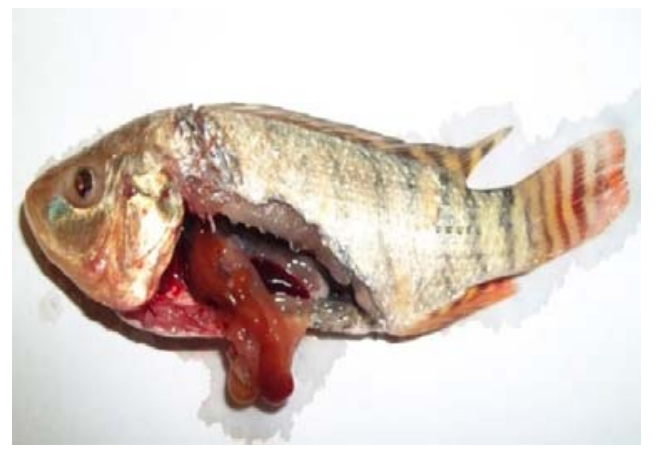

(4)

Fig. 1: $O$. niloticus fed on diet contains $\mathrm{AFB}_{1} 100 \mu \mathrm{g} / \mathrm{Kg}$ showed hepatomegaly with pale colour.

Fig. 2: $O$. niloticus fed on diet contains $A_{F} B_{1} 100 \mu \mathrm{g} / \mathrm{Kg}$ showed hepatomegaly, clear distended gall bladder.

Fig. 3: O. niloticus fed on diet contains $A_{F B} 100 \mu g / K g$ showed enlarged of gall bladder and empty intestinal tract.

Fig. 4: O. niloticus fed on diet contains $\mathrm{AFB}_{1} 20 \mu \mathrm{g} / \mathrm{Kg}$ showed spleenomegaly and normal liver. 


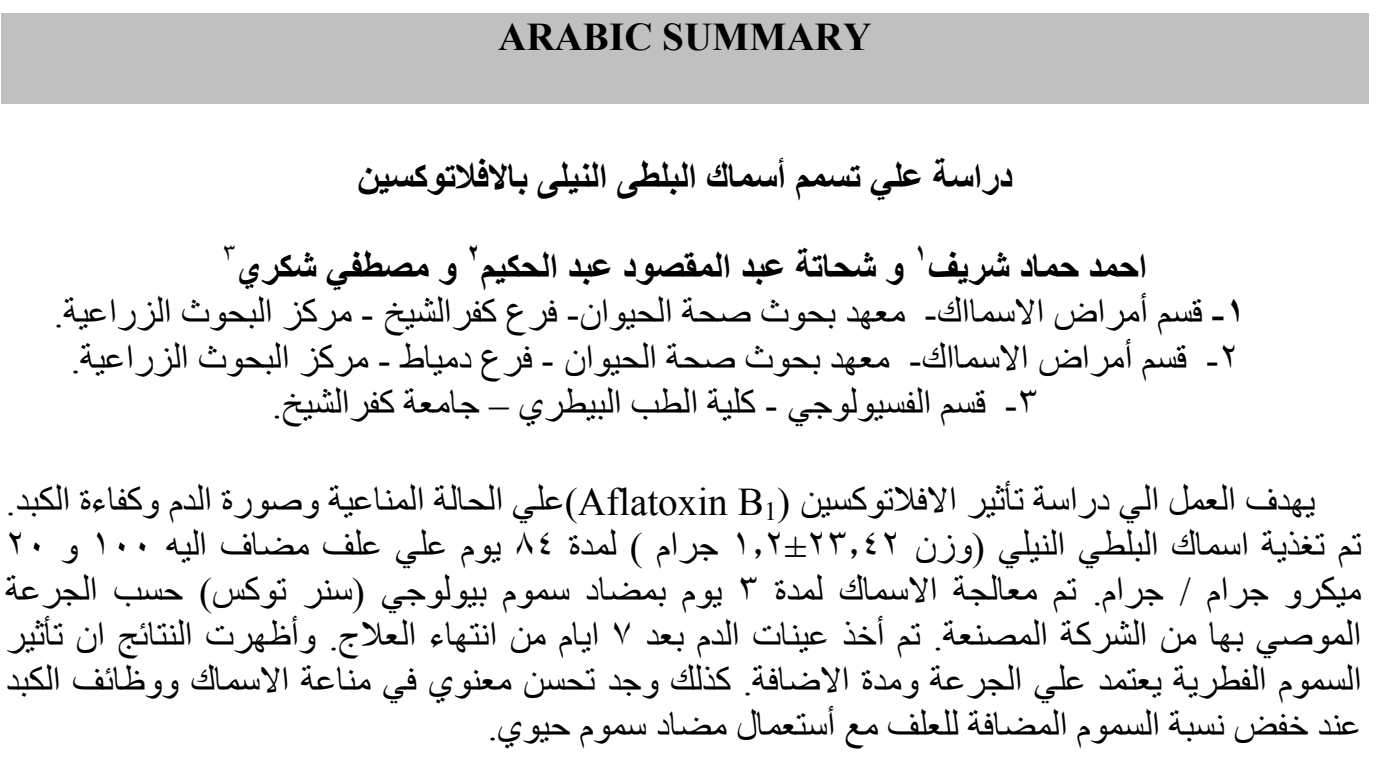

